\title{
Comparing morphological traits of legs of understory birds inhabiting forest areas with closed canopies and forest gaps
}

\author{
SUPALAK SIRI ${ }^{1}$, YUWADEE PONPITUK ${ }^{1}$, MONGKOL SAFOOWONG ${ }^{2}$, WIMONMART NUIPAKDEE $^{3}$, \\ DOKRAK MAROD ${ }^{1}$, PRATEEP DUENGKAE ${ }^{1, \vee}$ \\ ${ }^{1}$ Department of Forest Biology, Faculty of Forestry, Kasetsart University. 50 Ngamwongwan Rd., Chatuchak, Bangkok 10900, Thailand. \\ Tel.: +66-2-579-0176, Fax.: +66-2942-8107, `email: prateep.du@ku.ac.th \\ ${ }^{2}$ Deparment of National Park, Wildlife and Plant Conservation, Doi Chiang Dao Wildlife Research Station, Wildlife Research Division, \\ Wildlife Conservation Bureau. Chiang Mai 50170, Thailand \\ ${ }^{3}$ Mae Sa-Kog Ma Biosphere Reserve, Chiang Mai, Thailand
}

Manuscript received: 28 December 2019. Revision accepted: 13 February 2020.

\begin{abstract}
Siri S, Ponpituk Y, Safoowong M, Nuipakdee W, Marod D, Duangkae P. 2020. Comparing morphological traits of legs of understory birds inhabiting forest areas with closed canopies and forest gaps. Biodiversitas 21: 1041-1048. Bird species exhibit different adaptations depending on their habitats. The morphological traits of each species represent adaptations that are impacted by environmental changes. We conducted a 3-year study from 2015 to 2017 to compare the leg morphology of understory birds that occur under closed canopies and in forest gaps in a hill evergreen forest in northern Thailand, with gaps in the natural forest representing forest disturbances. We captured 64 bird species over the study period and measured 11 leg morphological features for each individual. Ground-foraging birds were generally long-legged and climbing birds generally short-legged. Understory species living in dense forest areas were significantly associated with long claws, toes, and tibiae, whereas species occurring in gaps and open areas tended to have shorter leg structures. Results from classification tree analysis revealed that digit claw length is the most important trait for predicting which habitat a species is most likely to occupy. Our findings suggest that understory birds with long leg structures that live under closed canopies are most vulnerable to forest disturbances or the conversion of forests to large-scale open areas.
\end{abstract}

Keywords: Bird, classification tree, disturbance, hill evergreen forest, Thailand

\section{INTRODUCTION}

The varying responses of different species to habitat changes may be related to their functional traits (Newbold et al. 2012). Thus, the examination of species functional traits can help with predicting how a species may respond to environmental changes, and contribute to its conservation and management.

A functional trait is a feature of an organism that has a demonstrable link to the organism's niche or role in ecosystem functioning (Garnier et al. 2004; Raffaelli and Frid 2010). Functional traits provide a general method to describe an organism's structure and function, based on measurable properties, within the context of the greater community or environmental change (Ames 2012). Trait variation is a focus of evolutionary ecology, as examining variation allows us to determine adaptations to different environmental conditions (McNamara and Houston 1990; MacLeod et al. 2008). More recently, functional traits have been suggested as a useful conservation tool for birds, acting as predictors of groups of species that may be more vulnerable to habitat loss, forest succession, land-use change, and climate change (Violle et al. 2007; Gilroy et al. 2014; Thuiller et al. 2014; Srinivasan 2019). In this study, we will discuss traits in terms of morphology.

The study of ecological morphology focuses on understanding the relationship between morphological trait variation in birds and their ecosystem (Payne and Risley
1976). Similarities in the external morphology of birds that behave in similar ways can be evaluated by comparing the size or shape of birds occupying the same microhabitats (James 1982). Zeffer et al. (2003) suggested that simple leg morphology can reflect the response of birds to their environment. The lengths of the tarsus and midtoe indicate strong relationships with substrate utilization (Miles and Ricklefs 1984). It' is clear that a strong correlation between morphological and ecological characteristics generally reflects an association between form and function (Kennedy et al. 2019).

In Thailand, information on bird functional traits is lacking. Timely research into traits such as leg morphology can provide the data necessary for species conservation. In this study, we used leg morphological traits, rather than taxonomic species, to evaluate bird responses to changes in forest structure in hill evergreen forests in Thailand. Marod and Kutintara (2009) and $\mathrm{Vu}$ (2009) found that biodiversity in hill evergreen forests has been declining at a rapid rate, primarily due to habitat degradation. In addition, bird functional traits have not been well-explored in montane habitats, and little is known about differences in the leg morphology of understory birds in this habitat type in Thailand. To address these knowledge gaps, we investigated how leg morphological traits are adapted to closed-canopy conditions and mid-sized forest gaps. In natural systems, the forest canopy is dynamic - changing continuously through growth, death, disturbance, and 
succession. Forest gaps or patches ranging from 10 to $5,000 \mathrm{~m}^{2}$ can occur naturally as a result of tree death or disturbance events such as wind (Desouza et al. 2001; Schliemaun and Bockheim 2011).

Previous work has classified species into functional groups using phylogenetics, discriminant analysis, and ordination (e.g., principal components analysis; Dehling et al. 2016; Shao et al. 2016; Rolo et al. 2017; Shatkovska and Ghazali 2017). Here, we used classification trees to distinguish groups, with the intention of presenting a new approach to analyzing understory mainland bird species in Southeast Asia. Understory birds were selected because they are known to be good indicators of forest disturbance, and evidence suggests that birds in primary forests in Asia may be more sensitive to disturbance than forest birds on other continents (Sreekar et al. 2015; Powell et al. 2013; Phillips et al. 2017). Research into leg functional traits is useful to guide avian habitat conservation and ecosystem management in tropical forests.

\section{MATERIALS AND METHODS}

\section{Study area}

Our study was conducted in a 16-ha permanent plot in the Mae Sa-Kog Ma Biosphere Reserve (HKM) (18 48'45.7' N, 98 54'7.7' E) in northern Thailand. Mean annual precipitation is $1,736 \mathrm{~mm}$, with peak rainfall (335 $\mathrm{mm} / \mathrm{month}$ ) in August during the rainy season (Glomvinya et al. 2016). Elevation within the HKM ranges between 1,250 and $1,540 \mathrm{~m}$.

The vegetation within the 16-ha permanent plot is mature hill evergreen forest. To date, 189 plant species have been found in this forest. Dominant plant species include Castanopsis acuminatissima (Blume) A.DC., Castanopsis armata (Roxb.) Spach, Styrax benzoides Craib, Schima wallichii (DC.) Korth., and Vernonia volkameriiolia Wall. ex DC. (Marod et al. 2014). The dominant bird feeding guild is foliage-gleaning insectivores, which includes species such as Alcippe morrisonia Swinhoe, 1863, Stachyris nigriceps Blyth, 1844, Pellorneum tickelli Blyth, 1859, and Seicercus omeiensis (Martens, Eck, Päckert \& Sun, 1999) (Siri et al. 2013; Siri et al. 2019).

\section{Mist-netting}

Understory birds were captured using mist-nets at 18 randomly selected sites within the permanent plot between
January 2015 and December 2017. Nine sites were located under closed canopies (UCC) and each UCC site was paired with a forest gap (FG). We defined forest gaps as foliage-free areas within the forest canopy. The distance between each pair of UCC and FG sites was approximately $10 \mathrm{~m}$. All gaps were $200-600 \mathrm{~m}^{2}$ in size. Each month, we set 72 mist nets $(2.5 \mathrm{~m} \mathrm{x} 9 \mathrm{~m} \mathrm{x} 1 \mathrm{~m}$, with four shelves) in pairs at the UCC and FG sites. Nets were set for $10 \mathrm{~h}$ per day (from $6 \mathrm{AM}$ to $4 \mathrm{PM}$ ) and checked every 30-60 min, with greater frequency in the morning and evening. We closed the nets during periods of rainfall (Bibby et al. 1998; Wunderle et al. 2005; Werema 2015). All captured birds were identified to species.

Leg morphological traits were measured for 64 understory bird species. Eleven leg morphological traits in linear were measured using dial calipers graduated to a tenth of a millimeter (Table 1 and Figure 1). After identification and measurement, all mist-netted birds were released at their capture points. Activities complied with protocols from the Department of National Parks, Wildlife and Plant Conservation of Thailand (permit no. DNP 0907.4/9819).

\section{Data analyses}

Mean values for all 11 traits were compared between UCC and FG sites using t-tests, with differences significant at $\mathrm{P}<0.05$. Understory bird species were divided into four groups based on their behavior - ground, perching, climbing, and predatory (Birn-Jeffery et al. 2012). We also compared leg morphological traits among these behavioral categories using one-way analysis of variance (ANOVA) followed by a least significant differences test. Differences were significant at $\mathrm{P}<0.05$.
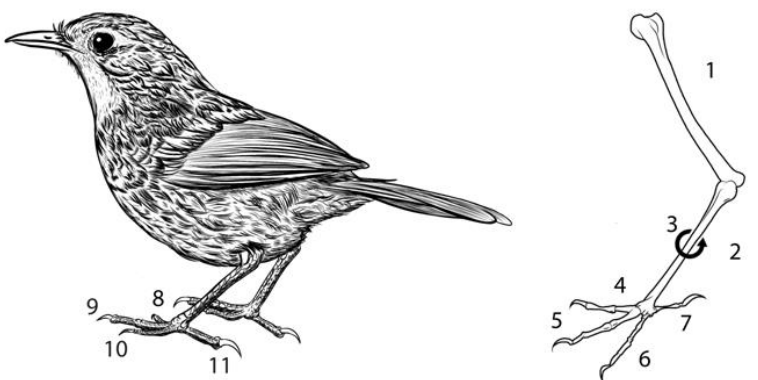

Figure 1. The leg structure of 11 traits: Tibia (1), Tarsus (2), Diameter of middle of tarsus (3), Inner toe (4), Middle toe (5), Outer toe (6), Digit toe (7), Inner claw (8), Middle claw (9), Outer claw (10), and Digit claw (11) - illustrated by Mallika Siri.

Table 1. Traits and methods used to measure leg morphological traits of birds (after Baldwin et al. 1931).

\begin{tabular}{|c|c|}
\hline Leg traits & Methods \\
\hline Tibia & From its junction with the femur to its junction with the metatarsus \\
\hline Tarsus & $\begin{array}{l}\text { From the exact middle point of the joint between the tibia and metatarsus behind, to the lower edge } \\
\text { of the undivided scute on the front of the junction of metatarsus with the base of the middle toe. }\end{array}$ \\
\hline Diameter of middle of tarsus & From antero-tarsus to posterior-tarsus at the middle point \\
\hline Toe (inner, middle, outer, digit) & $\begin{array}{l}\text { From the lower edge of the lowest entire tarsus scute, to its distal end where its integument ends on } \\
\text { the base of the claw }\end{array}$ \\
\hline Claw (inner, middle, out, digit) & From the tip of the claw to the base of the toe \\
\hline
\end{tabular}


In recent years, classification and regression tree (CART) analysis has become more popular among ecologists analyzing complex data, as it yields simple explanations and high classification accuracy (Cutler et al. 2007). We used a CART approach to classify birds into groups based on their leg morphological traits and to determine the associations between bird species and habitat type (UCC or FG). Consistent classification trees were constructed using the "rpart" package in R software (ver. 3.1.1; R Core Team 2014). The CART method effectively selects the important variables that are used to split groups in decision tree models (Kováth and Harnos 2015), in which each split partitions the data into two exclusive groups. The best predictor variables are shown at the top of the classification tree, and the length of the tree reflects its ability to explain the observed variation.

\section{RESULTS AND DISCUSSION}

\section{Morphological traits of understory birds}

Over two years of mist-netting, 969 birds representing 4 orders, 26 families, and 64 species were captured during 25,920 net hours at UCC and FG sites. Of all captured birds, 492 birds from 52 species were captured at UCC sites, and 477 birds from 48 species were captured at FG sites (Table 2). Ten of the 11 leg morphological traits were significantly different $(\mathrm{P}<0.05)$ between birds that occupy UCC and FG sites (Table 2). Leg structures tended to be longer in birds occupying under closed canopy than in birds occupying FG sites.

Correlations between leg morphology and behavioral group (ground, perching, and climbing) are presented in Table 3. Predatory birds were not included in this analysis, as only one predatory species was observed in the study. Ground-dwelling birds such as Garrulax strepitans Blyth, 1855, Copsychus malabaricus (Scopoli, 1788), Enicurus sinensis Gould, 1866, and Pitta cyanea Blyth, 1843, had longer tibiae, tarsi, middle toes, and digit claws compared to perching and climbing birds. Perching birds such as Cyornis banyumas (Horsfiele, 1821), Alophoixus pallidus
(Swinhoe, 1870), Rhipidura albicollis (Vieillot, 1818), and Arachnothera longirostra (Latham, 1790), had longer tibiae and tarsi than climbing birds. Finally, climbing birds had shorter legs, but longer outer toes and longer inner, middle, and outer claws compared to perching birds.

\section{Classification of understory birds occupying UCC and FC sites}

Results from classification tree analysis indicated that leg morphological traits can be used to predict habitat associations for understory birds. Lengths of the digit, middle, and outer claws; diameter of middle of tarsus, tarsus; digit, inner, and middle toes; and tibia were important in tree construction (Figure 2). Digit claw length was the most important variable that predicted bird species occur in the two habitat types (UCC and FG). Birds with long digit claws; digit, inner, and middle toes; tibiae, and middle claws were associated with UCC sites (Figure 2). In particular, birds with digit claws that were $>6.45 \mathrm{~mm}$ in length and inner toes that were $>7.15 \mathrm{~mm}$ in length were associated with UCC sites. These traits were found in 28 bird species in this study, including Myiomela leucura (Hodgson, 1845), Serilophus lunatus (Gould, 1834), Niltava sundara Hodgson, 1837, and Garrulax chinensis (Scopoli, 1786) (Table 4). In addition, bird species such as Turdus dissimilis Blyth, 1847 and Psilopogon asiaticus (Latham, 1790) had digit claw, middle toe, tibia, and digit toe lengths of $<6.45,>9.05,>19.15$, and $>10.05 \mathrm{~mm}$, respectively, and were found at UCC sites. Understory birds that were most active at FG sites had shorter digit claws $(<6.45 \mathrm{~mm})$ and middle toes $(<9.05 \mathrm{~mm})$. FG species with these traits include Aethopyga saturata (Hodgson, 1836), Phylloscopus intensior Deignan, 1956, Dicaeum ignipectus (Blyth, 1843), and Erpornis zantholeuca (Blyth, 1844). Additionally, understory birds found at FG sites had relatively short diameters of middle of tarsus $(<2.75 \mathrm{~mm})$, tibiae $(<19.15 \mathrm{~mm})$, and inner toes $(<7.15 \mathrm{~mm})$. These bird species include Terpsiphone affinis (Blyth, 1846), Pycnonotus melanicterus (Gmelin, 1789), Arachnothera longirostra (Latham, 1790), and Sasia ochracea Hodgson, 1836.

Table 2. Mean \pm SE on leg morphological of birds between under closed canopy (UCC) and forest gap (FG).

\begin{tabular}{|c|c|c|c|c|}
\hline \multirow{2}{*}{ Leg traits } & \multirow{2}{*}{ Code } & \multicolumn{2}{|c|}{ Mean \pm SE (mm.) } & \multirow{2}{*}{$\mathbf{P}$} \\
\hline & & $\mathrm{UCC}(\mathrm{n}=492)$ & FG $(n=477)$ & \\
\hline Tibia & Tibia & $29.53 \pm 0.35$ & $27.80 \pm 0.35$ & 0.00 \\
\hline Tarsus & Tarsus & $21.62 \pm 0.26$ & $20.23 \pm 0.26$ & 0.00 \\
\hline Diameter of middle of tarsus & Mtarsus & $2.19 \pm 0.06$ & $2.03 \pm 0.03$ & 0.00 \\
\hline Inner toe & T.inner & $9.17 \pm 0.11$ & $8.55 \pm 0.11$ & 0.00 \\
\hline Middle toe & T.middle & $13.53 \pm 0.16$ & $12.38 \pm 0.16$ & 0.00 \\
\hline Outer toe & T.outer & $10.52 \pm 0.11$ & $10.07 \pm 0.12$ & 0.00 \\
\hline Digit toe & T.digit & $9.68 \pm 0.12$ & $9.20 \pm 0.12$ & 0.00 \\
\hline Inner claw & C.inner & $4.20 \pm 0.04$ & $4.12 \pm 0.05$ & 0.01 \\
\hline Middle claw & C.middle & $5.42 \pm 0.04$ & $5.19 \pm 0.05$ & 0.00 \\
\hline Outer claw & C.outer & $4.00 \pm 0.04$ & $3.95 \pm 0.04$ & 0.38 \\
\hline Digit claw & C.digit & $6.56 \pm 0.07$ & $6.06 \pm 0.07$ & 0.00 \\
\hline
\end{tabular}


Table 3. Mean $\pm \mathrm{SE}$ on leg structure of understory birds follows behavioral categories. Values with different superscript in the same column indicate a significant different at $\mathrm{P}<0.05$.

\begin{tabular}{lccc}
\hline \multirow{2}{*}{ Leg traits } & \multicolumn{3}{c}{ Behavioural categories } \\
\cline { 2 - 4 } & Ground $(\mathbf{n = 9 8})$ & Perch $\left(\mathbf{n}=\mathbf{8 3 3}^{\mathbf{9}}\right)$ & Climb $(\mathbf{n = 3 1})$ \\
\hline Tibia & $45.34 \pm 1.26^{\mathbf{a}}$ & $26.95 \pm 0.14^{\mathbf{b}}$ & $23.18 \pm 1.22^{\mathbf{c}}$ \\
Tarsus & $33.30 \pm 0.97^{\mathbf{a}}$ & $19.75 \pm 0.09^{\mathbf{b}}$ & $14.56 \pm 0.88^{\mathbf{c}}$ \\
Mtarsus & $3.24 \pm 0.10^{\mathbf{a}}$ & $1.98 \pm 0.03^{\mathbf{b}}$ & $1.98 \pm 0.11^{\mathbf{b}}$ \\
T.inner & $13.84 \pm 0.37^{\mathbf{a}}$ & $8.30 \pm 0.05^{\mathbf{b}}$ & $8.30 \pm 0.54^{\mathbf{b}}$ \\
T.middle & $20.58 \pm 0.49^{\mathbf{a}}$ & $12.08 \pm 0.07^{\mathbf{b}}$ & $12.60 \pm 0.69^{\mathbf{b}}$ \\
T.outer & $15.02 \pm 0.38^{\mathbf{a}}$ & $9.71 \pm 0.06^{\mathbf{b}}$ & $11.06 \pm 0.23^{\mathbf{c}}$ \\
T.digit & $14.07 \pm 0.38^{\mathbf{a}}$ & $8.93 \pm 0.06^{\mathbf{b}}$ & $9.11 \pm 0.91^{\mathbf{b}}$ \\
C.inner & $5.23 \pm 0.14^{\mathbf{a}}$ & $4.01 \pm 0.02^{\mathbf{b}}$ & $4.90 \pm 0.38^{\mathbf{a}}$ \\
C.middle & $6.77 \pm 0.15^{\mathbf{a}}$ & $5.10 \pm 0.03^{\mathbf{b}}$ & $6.40 \pm 0.37^{\mathbf{a}}$ \\
C.outer & $4.88 \pm 0.13^{\mathbf{a}}$ & $3.81 \pm 0.02^{\mathbf{b}}$ & $5.08 \pm 0.21^{\mathbf{a}}$ \\
C.digit & $8.88 \pm 0.23^{\mathbf{a}}$ & $6.05 \pm 0.03^{\mathbf{b}}$ & $5.62 \pm 0.47^{\mathbf{b}}$ \\
\hline
\end{tabular}

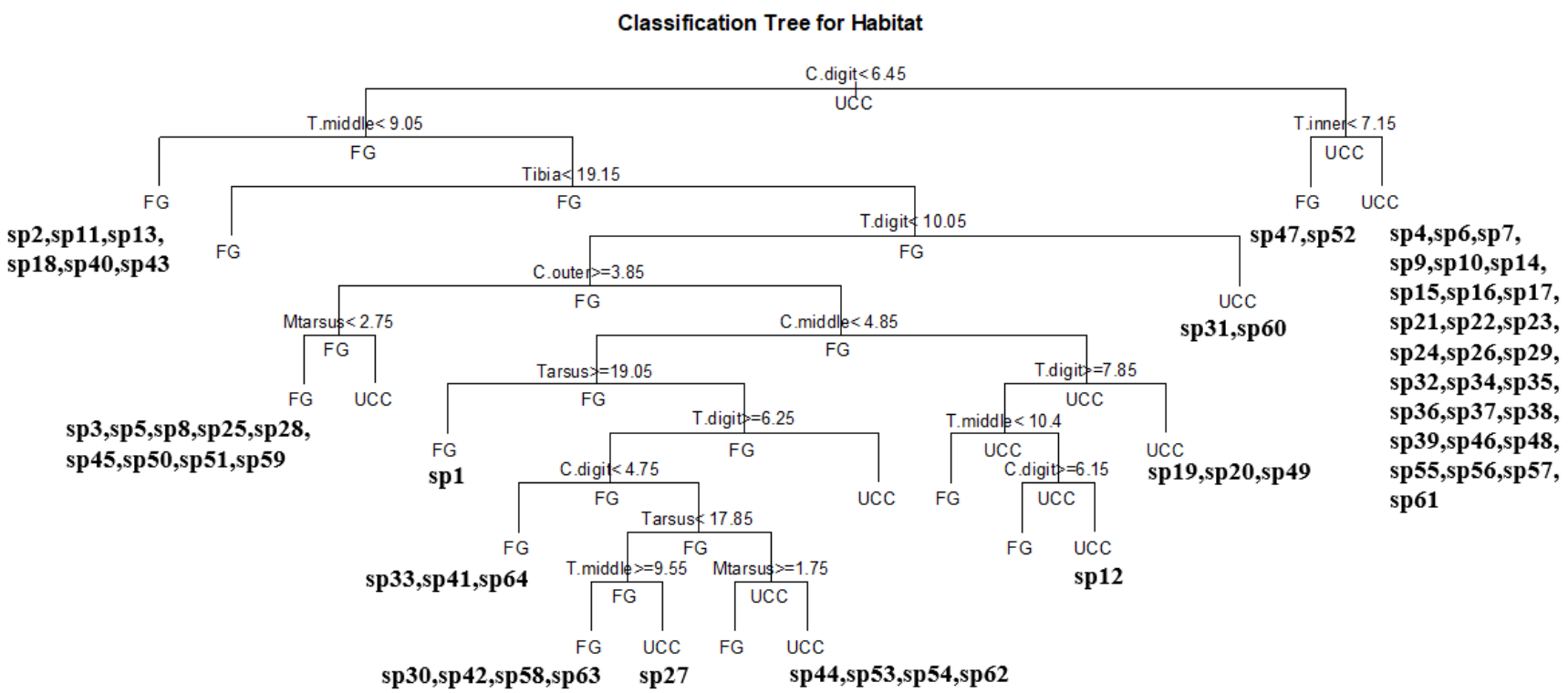

Figure 2. Classification tree model of the morphological traits of understory birds in under closed canopy (UCC) and forest gap (FG). Consider only leg structure, nine morphological traits (C.digit, C.middle, C.outer, Mtarsus, T.digit, T.inner, T.middle, Tarsus, and Tibia). Scientific name: See Table 4

\section{Discussion}

Morphological traits of understory birds

Variation in morphological traits among birds allows different species to occupy different habitats, and birds further express a variety of behaviors associated with these habitats (Grant 1986; Barbosa and Moreno 1999). At UCC sites, understory birds generally had longer leg structures. Most species with longer legs were ground-dwelling species that were largely insectivorous, such as Geokichla citrina (Latham, 1790), Turdus obscurus Gmelin, 1789, Garrulax monileger (Hodgson, 1836), and Pellorneum ruficeps Swainson, 1832. These species use their long legs for walking or hopping, to forage for insects in dense leaf litter (Dilger 1956; Marod and Kutintara 2009), and to maintain stability when crouching (Stover 1960; Bennett 1996). A long, flat digit claw (hind claw) is an adaptation for walking in this group (Osterhaus 1962). Our findings were consistent with those reported by Siri et al. (2019), that terrestrial insectivores were more likely to be captured under closed canopies than in forest gaps.

Mean leg structure lengths in perching birds were intermediate between those in climbing and grounddwelling birds. A long toe found in perching birds is common to foliage-gleaning insectivores such as Stachyris nigriceps Blyth, 1844, Abroscopus superciliaris (Blyth, 1859), Mixornis gularis (Horsfield, 1822), and Phylloscopus valentini (Hartert, 1907) which forage over short distances. Osterhaus (1962) suggested that long toes are critical for the stability needed to perch on small twigs or branches. In particular, flycatchers such as Culicicapa ceylonensis (Swainson, 1820) and Hypothymis azurea (Boddaert, 1783) have a long middle toe that helps them 
with taking off quickly to capture insects in the air (Osterhaus 1962). Moreover, Xing et al. (2019) discovered this longer toe has a specific function of support in prey detection.

Shorter leg structures were more common among species found in forest gaps, such as Picumnus innominatus Burton, 1836, Sasia ochraceu, and Sitta frontalis Swainson, 1820, which are bark-gleaning insectivores (Round et al. 2011). These species forage in trees and climb vertically up tree trunks. Thus, their short legs are an adaptation to climbing (Zeffer et al. 2003). A short tibia and tarsus are advantageous for climbing, as these traits provide support for the body against trees or other substrates (Richardson 1942; Osterhaus 1962; Winkler and Bock 1976). Furthermore, we found longer claws in climbing birds relative to perching birds. Longer claws and higher curvature allow understory birds to climb and grasp onto tree bark more effectively (Birn-Jeffery et al. 2012). Thus, leg structure depends on a species' foraging substrate and is related to species behavior.

\section{Classification of understory birds occupying UCC and FG sites}

The classification tree developed here using leg morphological traits was effective in predicting which bird species would occupy UCC or FG sites, and suggested that 38 of the understory species found in this study should occur under a closed canopy or in dense forest. Broadly, birds expected to occur under closed canopy had a high habitat specificity, low mobility, and preferred dense forests to open areas (Thiollay 1992; Stratford and Stouffer 1999; Siri et al. 2019). Forests with high structural complexity and high basal area provide important resources for closed canopy, long-legged species (Whelan 2001; Pratumtong et al. 2018), where these species benefit from diverse foraging opportunities in forests with high vertical stratification. Walther (2002) suggested that bird species foraging at low levels in dense forests can be found in small forest gaps with lower light intensities, as they require less illumination. However, in our study, longlegged understory birds spent most of their foraging time at high levels in dense forests, and species such as Pteruthius flaviscapis (Temminck, 1835), Dicrurus aeneus Vieillot, 1817, Hypothymis azurea, and Arachnothera magna (Hodgson, 1837) were found in large natural forest gaps. Thus, if hill evergreen forests are converted to large open gaps, ground-dwelling insectivorous birds with long legs are likely to be most severely affected (Figure 3) (Greenberg 1989; Stratford and Stouffer 2015). Based on our research, Pitta cyanea a ground-dwelling insectivorous species with long legs, is the most sensitive to large forest gaps. Previous studies suggest that species which have large body size, are sedentary and specific in habitat and diet tend to suffer more from habitat disturbance (Becker et al. 2007; Cleary et al. 2007; Tscharntke et al. 2008).

In tropical forests, anthropogenic conversion of natural habitats has increased rapidly, and deforestation has led to the creation of large-scale open areas (Newbold et al. 2012; Powell et al. 2015). A continued increase in the extent of open areas caused by non-natural disturbances will affect forest-dependent understory birds (Karr and Freemark 1983). Here, forest gaps of 200-600 $\mathrm{m}^{2}$ represented forest disturbances. The most distinctive trait of birds occurring in forest gaps was shorter leg structures. Therefore, the fallen trees on the ground impacted the foraging substrate of these short-legged birds. Almost all understory birds associated with FG sites in this study catch insects by perching. The short legs, and especially the short tarsi, of perch-gleaning and sally-gleaning insectivores, increase stability when birds perch on thin branches or unstable surfaces (Schulenberg 1983).

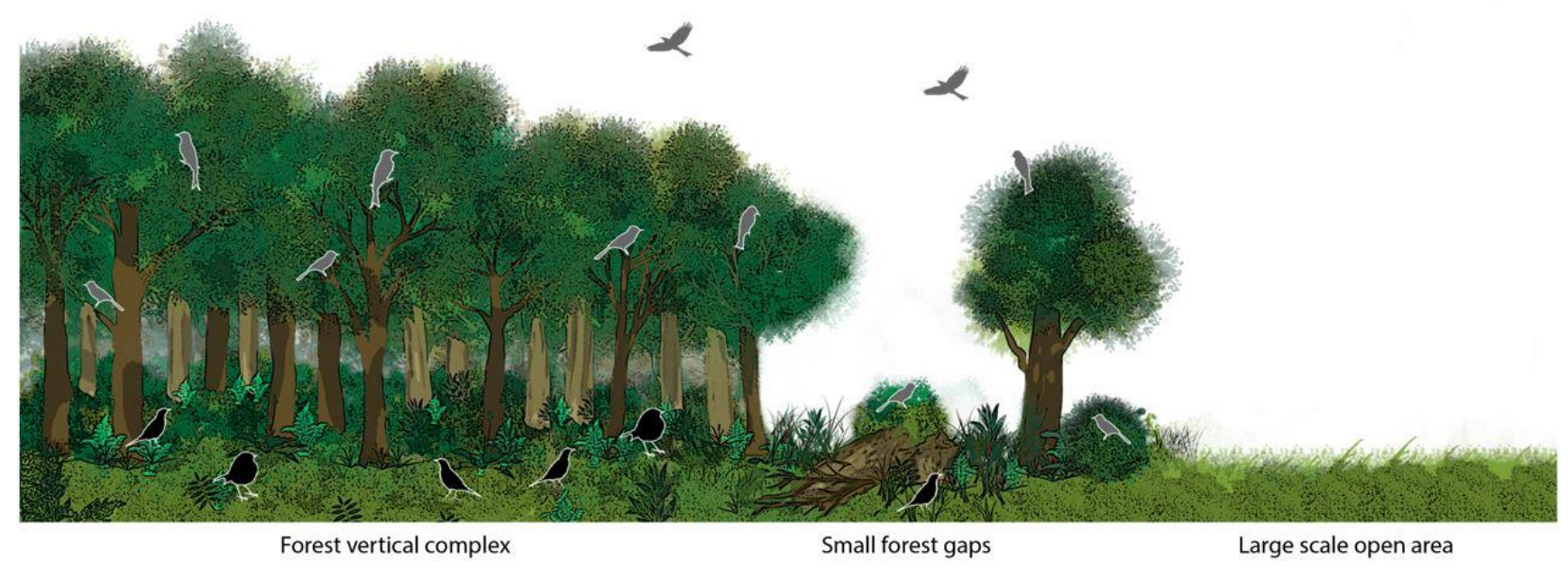

Figure 3. The long legs trait of ground-foraging species (in black) need low illumination in the UCC in hill evergreen forests and are more sensitive to large open areas. Bird with this trait but forage above the ground (grey) in the UCC can be found in natural forest gaps more than terrestrial birds. In the illustration, it is apparent that habitat structure and canopy have an effect on birds - illustrated by Mallika Siri. 
Table 4. Mean of 11 traits of understory birds for considering habitat type on classification tree. Abbreviation: See Table 2

\begin{tabular}{|c|c|c|c|c|c|c|c|c|c|c|c|}
\hline \multirow[b]{2}{*}{ Scientific name } & \multicolumn{11}{|c|}{ Leg traits $(\mathbf{m m})$} \\
\hline & 哥 & 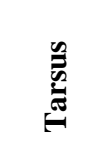 & 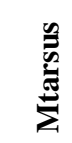 & $\stackrel{\mathscr{\Xi}}{\stackrel{\Xi}{\Xi}}$ & 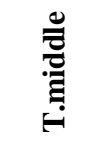 & 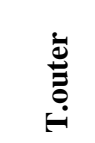 & & 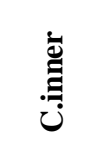 & 泀 & 营 & 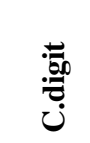 \\
\hline Abroscopus superciliaris & 23.90 & 21.60 & 1.40 & 7.70 & 10.80 & 9.80 & 9.10 & 3.60 & 4.80 & 3.50 & 5.50 \\
\hline Aethopyga saturata & 17.76 & 14.01 & 1.38 & 6.40 & 8.53 & 7.23 & 7.33 & 3.21 & 3.77 & 3.26 & 4.87 \\
\hline Alcippe morrisonia & 28.39 & 21.50 & 1.93 & 8.37 & 12.41 & 10.30 & 9.23 & 4.16 & 5.07 & 3.97 & 6.14 \\
\hline Alophoixus pallidus & 33.76 & 21.16 & 3.01 & 10.65 & 14.92 & 12.43 & 11.43 & 5.02 & 6.40 & 4.76 & 6.87 \\
\hline Arachnothera longirostra & 23.34 & 15.63 & 1.93 & 6.30 & 10.15 & 7.93 & 7.77 & 4.43 & 5.47 & 4.01 & 6.43 \\
\hline Arachnothera magna & 30.56 & 20.60 & 2.62 & 10.15 & 13.73 & 11.30 & 11.68 & 5.46 & 6.72 & 5.14 & 8.19 \\
\hline Chalcophaps indica & 51.36 & 28.43 & 4.73 & 18.66 & 23.20 & 18.66 & 16.03 & 6.16 & 7.06 & 5.10 & 7.30 \\
\hline Chloropsis hardwickii & 29.25 & 17.50 & 2.60 & 8.20 & 12.50 & 10.10 & 8.25 & 4.25 & 5.55 & 4.20 & 5.85 \\
\hline Clamator coromandus & 44.60 & 28.40 & 4.50 & 19.30 & 26.50 & 20.30 & 15.00 & 6.90 & 8.90 & 8.00 & 6.80 \\
\hline Copsychus malabaricus & 35.54 & 26.14 & 2.31 & 10.37 & 16.21 & 11.91 & 11.27 & 4.38 & 6.37 & 4.48 & 7.74 \\
\hline Culicicapa ceylonensis & 18.56 & 13.38 & 1.40 & 5.34 & 7.44 & 6.48 & 6.14 & 3.30 & 4.22 & 3.26 & 4.20 \\
\hline Cyornis banyumas & 25.02 & 17.98 & 1.85 & 8.11 & 12.00 & 8.95 & 8.35 & 3.64 & 5.02 & 3.48 & 5.73 \\
\hline Dicaeum ignipectus & 18.55 & 12.80 & 1.35 & 6.10 & 7.60 & 6.30 & 6.65 & 2.45 & 3.15 & 2.70 & 3.75 \\
\hline Dicrurus aeneus & 25.60 & 16.10 & 2.20 & 7.20 & 10.20 & 8.10 & 7.20 & 4.50 & 6.10 & 4.10 & 6.60 \\
\hline Dicrurus remifer & 31.80 & 20.90 & 2.70 & 9.85 & 13.75 & 12.20 & 11.25 & 6.05 & 6.70 & 5.65 & 9.10 \\
\hline Garrulax chinensis & 59.90 & 41.60 & 4.50 & 16.10 & 24.90 & 18.60 & 14.60 & 7.00 & 9.00 & 6.70 & 12.60 \\
\hline Enicurus sinensis & 40.87 & 31.25 & 2.82 & 13.20 & 19.02 & 13.65 & 13.00 & 4.70 & 5.70 & 4.07 & 7.97 \\
\hline Erpornis zantholeuca & 24.31 & 16.97 & 1.73 & 6.54 & 8.92 & 8.05 & 7.87 & 4.48 & 4.96 & 3.84 & 5.35 \\
\hline Erythrura prasina & 23.70 & 14.50 & 2.10 & 7.75 & 12.50 & 8.95 & 7.20 & 3.60 & 4.95 & 3.55 & 5.85 \\
\hline Ficedula hyperythra & 23.95 & 20.05 & 1.45 & 9.55 & 12.75 & 8.75 & 7.60 & 3.60 & 5.50 & 3.15 & 6.20 \\
\hline Garrulax strepitans & 62.24 & 47.20 & 4.83 & 18.40 & 27.33 & 20.33 & 19.24 & 7.18 & 8.70 & 6.68 & 12.18 \\
\hline Garrulax monileger & 61.27 & 44.97 & 4.82 & 18.92 & 26.47 & 19.07 & 18.07 & 6.65 & 8.90 & 6.72 & 12.35 \\
\hline Geokichla citrina & 46.33 & 33.12 & 3.19 & 13.62 & 20.34 & 14.90 & 13.65 & 4.77 & 6.78 & 4.54 & 8.22 \\
\hline Glaucidium brodiei & 41.30 & 20.50 & 3.60 & 15.30 & 17.80 & 14.20 & 10.60 & 8.30 & 8.40 & 7.30 & 7.70 \\
\hline Hemixos flavala & 28.95 & 16.75 & 2.65 & 8.10 & 12.30 & 9.95 & 9.25 & 3.90 & 5.15 & 4.00 & 5.55 \\
\hline Pitta cyanea & 60.93 & 48.36 & 3.46 & 16.43 & 24.90 & 18.53 & 17.56 & 5.56 & 7.66 & 4.40 & 9.76 \\
\hline Hypothymis azurea & 22.34 & 16.60 & 1.64 & 6.93 & 9.38 & 8.22 & 7.37 & 3.58 & 4.48 & 3.55 & 5.02 \\
\hline Hypsipetes mcclellandii & 27.69 & 18.14 & 2.52 & 9.25 & 12.88 & 10.70 & 8.88 & 4.25 & 5.38 & 4.07 & 5.85 \\
\hline Larvivora cyane & 32.50 & 25.10 & 1.80 & 9.20 & 14.70 & 9.20 & 9.90 & 3.30 & 4.80 & 3.00 & 6.50 \\
\hline Mixornis gularis & 24.66 & 17.62 & 1.92 & 7.60 & 11.00 & 8.74 & 8.92 & 3.66 & 4.50 & 3.26 & 5.94 \\
\hline Psilopogon asiaticus & 44.20 & 25.15 & 3.45 & 14.15 & 19.37 & 18.30 & 10.45 & 6.17 & 8.05 & 7.15 & 6.10 \\
\hline Monticola rufiventris & 37.90 & 26.50 & 3.30 & 12.50 & 20.20 & 14.20 & 13.50 & 5.90 & 7.20 & 5.70 & 8.60 \\
\hline Muscicapa ferruginea & 21.70 & 13.90 & 1.55 & 6.70 & 9.95 & 7.05 & 6.80 & 2.75 & 3.95 & 2.70 & 4.05 \\
\hline Myiomela leucura & 37.33 & 28.46 & 2.23 & 12.00 & 18.56 & 13.40 & 11.43 & 4.76 & 6.53 & 4.70 & 9.56 \\
\hline Myophonus caeruleus & 69.70 & 59.40 & 4.50 & 18.40 & 29.20 & 19.90 & 20.10 & 8.10 & 9.50 & 7.80 & 12.60 \\
\hline Napothera epilepidota & 28.30 & 22.30 & 2.10 & 10.95 & 17.10 & 12.10 & 10.65 & 4.15 & 4.70 & 3.45 & 6.58 \\
\hline Niltava sundara & 30.41 & 22.07 & 1.96 & 9.79 & 14.88 & 11.09 & 10.55 & 4.11 & 5.58 & 4.06 & 6.92 \\
\hline Pellorneum ruficeps & 33.42 & 25.24 & 2.42 & 10.91 & 16.84 & 11.87 & 11.28 & 4.12 & 5.39 & 3.90 & 7.69 \\
\hline Pellorneum tickelli & 33.06 & 26.21 & 2.15 & 10.59 & 15.92 & 11.68 & 10.61 & 4.01 & 5.81 & 3.61 & 8.19 \\
\hline Phylloscopus intensior & 22.90 & 17.60 & 1.30 & 6.46 & 8.83 & 7.06 & 7.06 & 2.90 & 3.30 & 2.73 & 4.13 \\
\hline Phylloscopus inornatus & 23.40 & 17.90 & 1.30 & 6.40 & 9.20 & 7.00 & 6.40 & 3.10 & 4.10 & 2.90 & 4.60 \\
\hline Phylloscopus reguloides & 22.95 & 17.72 & 1.39 & 6.95 & 9.92 & 7.74 & 7.72 & 3.19 & 3.91 & 3.19 & 4.85 \\
\hline Phylloscopus ricketti & 22.02 & 16.97 & 1.32 & 5.89 & 8.65 & 6.97 & 6.65 & 3.00 & 3.47 & 2.58 & 3.92 \\
\hline Phylloscopus tenellipes & 22.50 & 18.60 & 1.50 & 6.40 & 9.70 & 7.20 & 7.50 & 3.40 & 4.60 & 3.10 & 5.30 \\
\hline Picumnus innominatus & 20.71 & 12.22 & 1.71 & 7.47 & 11.07 & 10.76 & 5.88 & 4.02 & 5.53 & 4.71 & 3.82 \\
\hline Picus guerini & 47.95 & 31.30 & 4.15 & 18.85 & 25.30 & 14.25 & 23.30 & 12.75 & 13.81 & 7.55 & 11.55 \\
\hline Pomatorhinus schisticeps & 41.13 & 30.23 & 3.30 & 13.60 & 19.73 & 15.06 & 15.20 & 5.80 & 6.96 & 5.36 & 9.73 \\
\hline Pteruthius flaviscapis & 37.45 & 26.65 & 2.40 & 12.25 & 16.00 & 13.70 & 11.25 & 4.95 & 6.55 & 5.00 & 7.60 \\
\hline Pteruthius aeralatus & 25.36 & 19.76 & 1.70 & 7.28 & 10.26 & 8.78 & 7.57 & 3.43 & 4.31 & 3.42 & 5.01 \\
\hline Pycnonotus melanicterus & 27.56 & 16.18 & 2.55 & 8.53 & 11.56 & 9.35 & 8.14 & 3.51 & 4.68 & 4.02 & 4.94 \\
\hline Rhipidura albicollis & 23.55 & 18.20 & 1.71 & 6.83 & 10.09 & 8.75 & 7.41 & 3.96 & 5.08 & 3.96 & 5.81 \\
\hline Sasia ochracea & 21.37 & 13.00 & 1.90 & 7.07 & 11.02 & $\mathrm{NaN}$ & 11.55 & 4.72 & 7.45 & $\mathrm{NaN}$ & 7.75 \\
\hline Phylloscopus omeiensis & 22.61 & 18.26 & 1.38 & 6.85 & 9.90 & 8.08 & 7.42 & 3.21 & 4.47 & 3.17 & 5.40 \\
\hline Phylloscopus valentini & 22.36 & 18.76 & 1.37 & 6.94 & 10.10 & 8.02 & 7.77 & 3.28 & 4.54 & 3.08 & 5.54 \\
\hline Serilophus lunatus & 29.95 & 20.44 & 2.28 & 10.38 & 14.97 & 13.20 & 12.16 & 5.52 & 6.78 & 5.28 & 7.11 \\
\hline Sitta frontalis & 23.95 & 17.43 & 2.11 & 8.21 & 14.25 & 10.91 & 12.95 & 5.16 & 5.98 & 5.41 & 7.95 \\
\hline Stachyris nigriceps & 29.39 & 21.97 & 2.40 & 8.85 & 12.23 & 10.21 & 9.67 & 4.58 & 5.52 & 4.07 & 7.13 \\
\hline Staphida castaniceps & 23.00 & 16.40 & 1.80 & 7.10 & 11.20 & 8.20 & 6.70 & 3.20 & 3.70 & 2.90 & 4.80 \\
\hline Terpsiphone affinis & 25.10 & 15.53 & 1.96 & 7.06 & 10.46 & 8.70 & 8.53 & 4.40 & 5.66 & 4.53 & 6.13 \\
\hline Turdus dissimilis & 45.30 & 30.10 & 3.60 & 14.90 & 22.70 & 16.70 & 15.00 & 9.10 & 6.00 & 7.80 & 5.90 \\
\hline Turdus obscurus & 45.00 & 30.05 & 3.15 & 14.85 & 22.10 & 14.90 & 14.45 & 6.05 & 7.60 & 5.50 & 9.10 \\
\hline Urosphena squameiceps & 24.48 & 18.81 & 1.42 & 8.40 & 12.54 & 8.48 & 8.65 & 3.15 & 3.81 & 2.74 & 5.68 \\
\hline Zosterops erythropleurus & 23.25 & 15.97 & 1.67 & 7.32 & 10.45 & 8.97 & 8.65 & 3.25 & 4.22 & 3.17 & 4.82 \\
\hline Zosterops palpebrosus & 21.25 & 15.00 & 1.59 & 6.70 & 9.20 & 7.80 & 7.65 & 2.80 & 3.35 & 2.65 & 4.55 \\
\hline
\end{tabular}


From our results, we can predict which understory bird species in the HKM are likely to be negatively impacted by artificially-created large open areas, based on leg morphological traits. Specifically, species occurring under closed canopies with long digit claws and toes; middle claws; inner and middle toes; and tibiae are most likely to be negatively affected by disturbance. Results from classification tree analysis revealed that leg morphological traits can be used to associate bird species with habitat type. We note that our findings are limited to understory birds in hill evergreen forests but suggest that they can be used to understand where bird species are most likely to occur in general. Functional traits represent phenotypic plasticity in birds and dictate which birds may be able to adapt to novel environments when short-term environmental changes occur (Nussey et al. 2007; Pfenning et al. 2010). Long-term monitoring that focuses on relationships between leg traits and forest gap succession in this region would provide useful data and should be a priority for future research.

\section{ACKNOWLEDGEMENTS}

We would like to thank the National Research Council of Thailand (Project: Biodiversity Monitoring on the Climate Changes in Huai Kog Ma Biosphere Reserve and Adjacent Area of Doi Suthep-Pui Mountain Ecosystems, Chiang Mai Province), and the Kasetsart University Research and Development Institute (KURDI). Prateep Duengkae is the recipient of a Research Chair Grant from the National Science and Technology Development Agency (NSTDA), Thailand. We are grateful to the individuals who collected data at the Kog Ma, with special thanks to Wachirapon Khumbucha, Niwat Intawin, Bunjerd Kiriya, Pongsit Srikhunmuang, Apisada Rueangket, Maratreenung Seehakrai, Ngamphrom Sukgosa, Suttikarn Srisodsuk, Nutthakarn Boonpha, and Thansuda Daoriangkan.

\section{REFERENCES}

Ames GM. 2012. Using species functional traits to predict community dynamics. [Dissertation]. Colorado State University, Colorado. [USA]

Baldwin SP, Oberholser HC, Worley LG. 1931. Measurements of birds. Cleveland Museum of Natural, Ohio.

Bennett MB. 1996. Allometry of the leg muscles of birds. J Zool Lond 238: 435-443.

Bibby C, Jones M, Marsden S. 1998. Expedition field techniques: bird surveys. Royal Geographical Society, London.

Barbosa A, Moreno E. 1999. Hindlimb morphology and locomotion performance in waders: an evolutionary approach. Biol J Linn Soc 67: $313-330$

Becker CG, Fonseca CR, Haddad CFB, Batista RF, Prado PI. 2007. Habitat split and the global decline of amphibians. Science 318: 1775 1777.

Birn-Jeffery AV, Miller CE, Naish D, Rayfield EJ, Hone DWE. 2012 Pedal claw curvature in birds, lizards and Mesozoic dinosaurs complicated categories and compensating for mass-specific and phylogenetic control. PLoS One 7 (12): e50555. DOI: 10.1371/journal.pone.0050555
Cleary DFR, Boyle TJB, Setyawati T, Anggraeni CD, Van Loon EE, Menken SBJ. 2007. Bird species and traits associated with logged and unlogged forest in Borneo. Ecol Appl 17: 1184-1197.

Cutler DR, Edwards Jr TC, Beard KH, Cutler A, Hess KT, Gibson J, Lawler JJ. 2007. Random forest for classification in ecology. Ecology 88: 2783-2792.

Dilger WC. 1956. Adaptive modifications and ecological isolating mechanism in the thrush genera Catharus and Hylocichla. Wilson Bull 68: 171-199.

Desouza O, Schoereder JH, Brown V, et al. 2001. A theoretical overview of the processes determining species richness in forest fragment. In: Bierregaard RO Jr, Gascon C, Lovejoy TE, Mesquita R (eds). Lessons from Amazonia: The Ecology and Conservation of a Fragmented Forest. Yale Univ. Press, New Haven, London.

Dehling DM, Jordano P, Schaefer HM, et al. 2016. Morphology predicts species' functional roles and their degree of specialization in plantfrugivore interactions. Proc $\mathrm{R}$ Soc $\mathrm{B}$ Biol Sci DOI: 10.1098/rspb.2015.2444

Grant PR. 1986. Bill size, body size, and the ecological adaptation of bird species to competitive situations on island. Syst Zool 17: 319-333.

Greenberg R. 1989. Neophobia, aversion to open space, and ecological plasticity in song and swamp sparrows. Can J Zool 67: 1194-1199.

Garnier E, Cortez J, Billes G, et al. 2004. Plant functional markers capture ecosystem properties during secondary succession. Ecol Soc Am. 85: 2630-2637.

Gilroy J, Uribe CAM, Haugaasen T, et al. 2014. Effect of scale on trait predictor of species responses to agriculture. Conserv Biol 29: 463472.

Glomvinya S, Tantasirin C, Tongdeenok P, et al. 2016. Change in rainfall characteristics at Huai Kog-Ma watershed, Chiang Mai Province. Thai J For 35: 66-77.

James FC. 1982. The ecological morphology of birds: a review. Animal Zoologici Fennici 19: 265-275.

Karr JR, Freemark KE. 1983. Habitat selection and environmental gradients: dynamics in the "stable" tropics. Ecological Society of America 64: 1481-1494.

Kennedy JD, Marki PZ, Fjeldsa J, Rahbek C. 2019. The association between morphological and ecological character across global passerine radiation. J Anim Ecol. DOI: 10.1111/1365-2656.13169

Kováts D, Harnos A. 2005. Morphological classification of conspecific birds from closely situated breeding areas - A case study of the Common Nightingale. Ornis Hung 23 (2): 20-30.

Miles DB, Ricklefs RE. 1984. The correlation between ecology and morphology in deciduous forest passerine birds. Ecology 65 (5): 1629-1640.

McNamara JM, Houston AI. 1990. The value of fat reserves and the tradeoff between starvation and predation. Acta Biotheor 38 (1): 37 61

MacLeod MG, Valentine J, Cowan A, Wade A, McNeil L, Bernard K. 2008. Metabolisable energy yield from a range of varieties in broilers, cockerels and turkeys. Br Poult Sci 49: 368-377.

Marod D, Kutintara U. 2009. Forest Ecology. Faculty of Forestry, Kasetsart University. Bangkok.

Marod D, Sungkaew S, Duengkae P, et al. 2014. Plant diversity of lower montane evergreen forest at Huai Kogma watershed area, Doi SuthepPui National Park, Chiang Mai province. In: Marod D, Thapyai C (eds) Thai forest ecological research network, T-FERN ecological knowledge for sustainable management. Naresuan University, 22-23 January 2015. [Thailand]

Nussey DH, Wilson AJ, Brommer JE. 2007. The evolutionary ecology of individual phenotypic plasticity in wild populations. J Evol Biol 20: 831-844.

Newbold T, Scharlemann JPW, Butchart SHH, et al. 2012. Ecological traits affect the response of tropical forest bird species to land-use intensity. Proc R Soc Lond. DOI: 10.1098/rspb.2012.2131

Osterhaus MB. 1962. Modifications in the leg structure of some North American Warblers. Am Midl Nat 68: 474-486.

Payne RB, Risley CJ. 1976. Systematics and evolutionary relationships among the Heron (Ardeidae). Museum of Zoology, University of Michigan, Michigan.

Pfenning DW, Wund MA, Snell-Rood EC et al. 2010. Phenotypic plasticity's impacts on diversification and speciation. Trends Ecol Evol. 25: 459-467. 
Powell LL, Stouffer PC, Johnson ET. 2013. Recovery of understory bird movement across the interface of primary and secondary Amazon rainforest. Auk 130: 459-468.

Powell T, Norbert J, Cordeiro J, Stratford A. 2015. Ecology and conservation of avian insectivores of the rainforest understory: a pantropical perspective. Biol Conserv 188: 1-10.

Phillips HRP, Newbold T, Purvis A. 2017. Land-use effects on local biodiversity in tropical forests vary between continents. Biodivers Conserv 26: 2251-2270.

Pratumtong D, Gale GA, Duengkae P, Pongpattananurak N, Chimchome V. 2018. The influence of environmental variables on bird communities in tropical seasonal forests, western Thailand. JWT 25: 49-65.

Richardson F. 1942. Adaptive modification for tree-trunk foraging in birds. Univ Calif Publ Zool 46: 317-368.

Raffaelli DG, Frid CLJ. 2010. Ecosystem Ecology: A New Synthesis. Cambridge University Press, Cambridge.

Round PD, Andrew JP, Wangworn S, George AG. 2011. The avifauna of the Mo Singto forest dynamics plot, Khao Yai National Park, Thailand. Nat Hist Bull Siam Soc 57: 57-80.

R Core Team. 2014. R: a language and environment for statistical computing, R Foundation for Statistical Computing, Vienna, Austria.

Rolo V, Olivier PI, van Aarde R. 2017. Tree and bird functional groups as indicators of recovery at generating subtropical coastal dune forest. Restor Ecol 25: 788-797.

Storer RW. 1960. Adaptive radiation in birds. In: Marshall AJ ed. Biology and comparative physiology of birds, Vol 1. Academic Press, New York.

Schulenberg TS. 1983. Foraging behavior, eco-morphology, and systematic of some antshrikes (Formicariidae: Thamnomanse) Wilson bull. 95: 505-521.

Stratford JA, Stouffer PC. 1999. Local extinctions of terrestrial insectivorous birds in a fragmented landscape near Manaus, Brazil. Conserv Biol 13: 1416-1423.

Schliemann SA, Bockheim JG. 2011. Methods for studying treefall gaps: a review. For Ecol Manag 261: 1143-1151.

Siri S, Duengkae P, Marod D. 2013. Species diversity and abundance of birds in hill evergreen forest permanent plot at Huai Kok Ma, Chiang Mai province. JWT. 20: 97-112.

Sreekar R, Srinivasan U, Mammides C, et al. 2015. The effect of land-use on the diversity and mass-abundance relationships of understory avian insectivores in Sri Lanka and southern India. Sci. Rep. 5: 11569 DOI: 10.1038/srep1 1569

Stratford JA, Stouffer PC. 2015. Forest fragmentation alters microhabitat availability for neotropical terrestrial insectivore birds. Biol Conserv 188: 109-115.
Shao S, Quan Q, Cai S, Qu Y, Lei F. 2016. Evolution of body morphology and beak shape revealed by morphometric analysis of 14 Paridae species. Front Zool 13: 30. DOI: 10.1186/s12983-016-0162-0

Shatkovska OV, Ghazali M. 2017. Relationship between developmental modes, flight styles and wing morphology in birds. Eur J Zool Res 84: 390-401.

Siri S, Ponpituk Y, Safoowong M, Marod D, Duengkae P. 2019. The natural forest gaps maintenance diversity of understory birds in Mae Sa-Kog Ma Biosphere Reserve, northern Thailand. Biodiversitas 20: 181-189.

Srinivasan U. 2019. Morphological and behavioral correlates of long-term bird survival in selectively logged forest. Front Ecol Evol 7: 17. DOI: $10.3389 /$ fevo.2019.00017

Thiollay JM. 1992. Influence of selective logging on bird species diversity in a Guianan rain forest. Conserv Biol 6: 47-63.

Tscharntke T, Sekercioglu CH, Dietsch TV, Sodhi NS, Hoehn P, Tylianakis JM. 2008. Landscape constraints on functional diversity of birds and insects in tropical agroecosystems. Ecology 89: 944-951.

Thuiller W, Pironon S, Psomas A, et al. 2014. The European functional tree of birdlife in the face of global change. Nat Commun 5: 3118 . DOI: $10.1038 /$ ncomms4118

Violle C, Navas ML, Vile D, Kazakou E, Fortunel C, Hummel I, Garnier E. 2007. Let the concept of trait be functional!. Oikos 116: 882-892.

$\mathrm{Vu}$ LV. 2009. Diversity and similarity of butterfly communities in five different habitat types at Tam Dao National Park, Vietnam. J Zool 277: 15-22.

Winkler H, Bock W. 1976. Analyse der Kräfteverhältnisse bei Klettervögeln. J Ornithol. 117: 397-418.

Whelan CJ. 2001. Foliage structure influences foraging of insectivorous forest bird: an experimental study. Ecol Soc Amer 82: 219-231.

Walther BA. 2002. Vertical stratification and use of vegetation and light habitat by Neotropical forest birds. J Ornithol 143: 64-81.

Wunderle JM, Willig RMR, Henriques LMP. 2005. Avian distribution in treefall gaps and understorey of terra firme forest in the lowland Amazon. Ibis. 147: 109-129.

Werema C. 2015. Seasonal variation in understory bird species diversity and abundance in the Uluguru Nature Reserve, Tanzania. Afr. J. Ecol. 54: 299-307.

Xing L, Jingmai K, Connor Q, et al. 2019. A new enantiornithine bird with unusual pedal proportions found in amber. Curr Biol 29 (14): 2396-2401.

Zeffer A, Johansson LC, Marmebro A. 2003. Functional correlation between habitat use and leg morphology in birds (Aves). Biol J Linn Soc. 79: 461-481 